\title{
Effects of Different Row Spacings and Different Fertilization Doses on the Seed Yield and Some Agronomic Characteristics of the Tall Fescue
}

\author{
${ }^{* 1}$ Mustafa Yilmaz \\ Sakarya University of Applied Sciences, Pamukova Vocational School, Sakarya/Turkey \\ mustafayilmaz@subu.edu.tr (iD \\ Research Paper \\ Arrival Date: 27.08.2019 \\ Accepted Date: 02.03.2020
}

\begin{abstract}
This research was carried out in the ecological conditions of the Pamukova district of the Sakarya province between November 2013-July 2016, in order to determine the seed yield and some yield properties of the tall fescue (Festuca arundinacea Schreb.) plant sown at different row spacings and with different fertilization doses. The experiment was conducted in the randomized block design with 4 different $\left(0,10,20\right.$ and $\left.30 \mathrm{~g} \mathrm{~m}^{-2}\right)$ fertilizer doses and at 2 different row spacings $(20$ and $40 \mathrm{~cm})$. In this research; vegetative shoot number $\left(\right.$ count $\left.\mathrm{m}^{-2}\right)$, seed yield $\left(\mathrm{g} \mathrm{m}^{-2}\right)$, straw yield $\left(\mathrm{g} \mathrm{m}^{-2}\right)$, biomass yield $\left(\mathrm{g} \mathrm{m}^{-2}\right)$, harvest index $(\%)$ and winter endurance (1-9 point) were determined. At the end of study, the highest values were obtained from in the $20 \mathrm{~cm}$ row spacings and $30 \mathrm{~g} \mathrm{~m}^{-2}$ fertilizer dose compare to control.
\end{abstract}

Keywords: Tall Fescue, Row spacing distance, Fertilizer dose, Seed yield, Agronomic characteristic.

\section{INTRODUCTION}

Turfgrasses are the most commonly used ground covering plants in recreational areas and areas used for sports, as well as for erosion prevention purposes. The rate of use of grass plants is proportional to the prevalence of green field cultures in the community.

The supply of seeds is one of the biggest problems encountered in our country concerning the spread of the culture of creating green areas. Today, the seeds of many widely used turf plants are purchased and sold despite lack of knowledge regarding seed species, varieties and species' name; insufficient data concerning seed quality, and absence of legislative regulation and authorized technical staff.

Although our country has very different and suitable ecological conditions for cultivating turfgrass used in creating green areas $[1,2,3,4]$ the total amount of turf seed produced annually is 300 tons on average, while in the same interval, turf seed of around 4700 tons is imported, amounting to a total of 5000 tons and resulting in $\$ 10$ million in expenses [5]. In order to save the country's resources and to obtain required seed, production needs to be established in areas suitable for domestic production.

The tall fescue plant is among important plants used for creating green areas in our country. It is known that agronomic applications such as row spacing and fertilization have important effects on the seed yields of plants [1,2].
Some researchers $[2,3,4,6,7,8,9$,$] have suggested combined$ (NPK) fertilizer doses differing between 15-10-10 and 4540-50 for good seed yield in Festuca arundinacea. Many researchers [1,2.3,4,10-26] have also reported extensive data and research results on some of its botanical characteristics.

This study aims to investigate the seed production potential and some yield properties of the Festuca arundinacea turf variety as an extensively used plant in the establishment of green areas in existing ecological conditions with different row spacings and application of nitrogen fertilizer at different doses.

\section{MATERIAL AND METHOD}

\subsection{Material}

The study was conducted in the research area of the Pamukova Vocational School of Sakarya University (N $40^{\circ}$ $30^{\prime} 20.462$, E $30^{\circ} 10^{\prime} 9.263$ and $80 \mathrm{~m}$ above sea level) for a 3-year period between 2013-2016.

The research area's long term climatic data and data for the period between November 2013-July 2016 are given in Table 1.

Table 1. The climate dates of Geyve for the years 20132016 and Long Term Average (L.T.A.) ${ }^{(*)}$ 


\begin{tabular}{lccc}
\hline Years & $\begin{array}{c}\text { Total } \\
\text { Prec. }(\mathrm{mm})\end{array}$ & $\begin{array}{c}\text { Average } \\
\text { Temp. }\left({ }^{\circ} \mathrm{C}\right)\end{array}$ & $\begin{array}{c}\text { Relative } \\
\text { Hum. }(\%)\end{array}$ \\
\hline $2013-14$ & 596.6 & 14.7 & 77.4 \\
$2014-15$ & 845.5 & 14.7 & 78.0 \\
$2015-16$ & 539.8 & 15.0 & 77.0 \\
\hline L.T.A. & 685.9 & 14.7 & 76.9 \\
\hline
\end{tabular}

(*): Meteorological Bulletin for Geyve/Sakarya.

Total precipitation in the $1^{\text {st }}$ and $3^{\text {rd }}$ year of the research was lower than long term average, but was higher in the $2^{\text {nd }}$ year. Average temperature data for the $1^{\text {st }}$ and $2^{\text {nd }}$ year was similar to long term data, but was relatively higher for the $3^{\text {rd }}$ year. Relative humidity values for all three years were very close to long term average.

Soil samples taken from $0-20$ and $20-40 \mathrm{~cm}$ depths of the research area were analyzed in the Sakarya University Pamukova Vocational School laboratory [27] and results were listed in Table 2.

Table 2. Soil properties of the research area.

\begin{tabular}{|c|c|c|}
\hline \multirow{2}{*}{ Properties } & \multicolumn{2}{|c|}{ Sample Depth $(\mathrm{cm})$} \\
\hline & $0-20$ & $20-40$ \\
\hline Structure & loamy & loamy \\
\hline $\mathrm{pH}$ & 6.70 & 7.61 \\
\hline Total salt (\%) & 0.024 & 0.023 \\
\hline $\mathrm{CaCO}_{3}(\%)$ & 5.61 & 7.50 \\
\hline Organic matter $(\%)$ & 1.61 & 1.14 \\
\hline Nitrogen $\left(\mathrm{kg} \mathrm{ha}^{-1}\right)$ & 1.12 & 0.65 \\
\hline $\mathrm{P}_{2} \mathrm{O}_{5}\left(\mathrm{~kg} \mathrm{ha}^{-1}\right)$ & 10.5 & 8.5 \\
\hline $\mathrm{K}_{2} \mathrm{O}\left(\mathrm{kg} \mathrm{ha}^{-1}\right)$ & 205.0 & 255.0 \\
\hline
\end{tabular}

According to analysis results, soil at $0-20 \mathrm{~cm}$ depth was determined as loamy-textured, having medium acid reaction; at middle range in terms of salinity, lime and organic matter, insufficient in total nitrogen and available phosphorus, and rich in potassium. Soil at 20-40 cm depth was identified as slightly alkaline and was in the same group in terms of other values.

The seed used in the research was the "Rebel XLR" variety of Festuca arundinacea, a variety released to market by the private sector.

\subsection{Method}

The research was conducted in a two-factor structure with two different row spacings (20 and $40 \mathrm{~cm}$ ) and four different nitrogen fertilizer doses $\left(0,10,20,30 \mathrm{~g} \mathrm{~m}^{-2}\right)$.

The experiment was set up in the randomized block design with 3 replications. Plot dimensions were arranged to form $20 \mathrm{~cm}$ row spacings of $5 \mathrm{~m} \times 1.60 \mathrm{~m}=8 \mathrm{~m}^{2}$ and $40 \mathrm{~cm}$ row spacings of $5 \mathrm{~m} \times 3.20 \mathrm{~m}=16 \mathrm{~m}^{2}$. The plots were established in accordance with the Technical Instructions Concerning Experiments on Value for Cultivation and Use [28].

Ammonium Nitrate $(33 \% \mathrm{~N})$ fertilizer was used as the source of fertilizer. The annual nitrogen fertilizer amount was separated into 3 equal parts and was administered every year during the period of tillering (March 25), before (April 25) and after (May 25) the period of heading. Soil analyses revealed insufficient phosphorus, thus triple superphosphate $\left(\mathrm{P}_{2} \mathrm{O}_{5} 42 \%\right.$, TSP) fertilizer was applied on an annual basis starting with the first year of sowing and continuing in later years around October at a rate of $10 \mathrm{~g} \mathrm{~m}^{-2}$ and, in this way, the phosphorus amount was kept steady.

The seeds were sown on 21 November 2013 into $2 \mathrm{~cm}$ depth in accordance with the $3 \mathrm{~g} \mathrm{~m}^{-2}[1,2,7,11]$ calculation. Irrigation was implemented using the sprinkler irrigation system. Weeds were combated using the hoeing method.

Seed harvest was performed when the seeds on panicles reached maturity; which was on 25 June 2014 for the first year, 5 July 2015 for the second year and 15 June 2016 for the third year. All panicles were dried at room temperature, grinded manually for separation of seeds, and sturdy seeds were isolated from empty seeds and glumes.

\subsection{Properties examined in the study}

Properties examined in the study were vegetative shoot number (count $\left.\mathrm{m}^{-2}\right)$, seed yield $\left(\mathrm{g} \mathrm{m}^{-2}\right)$, straw yield $\left(\mathrm{g} \mathrm{m}^{-2}\right)$, biomass yield $\left(\mathrm{g} \mathrm{m}^{-2}\right)$, harvest index (\%) (Anonymous, 2014) and winter endurance (1-9 point: 1: yellow, 9: dark green) [6].

\subsection{Evaluation of dataRussi}

Statistical analyses for the research data were carried out in a two-factor randomized blocks design, using the TARIST program [29] and according to row spacing, fertilizer dose and row spacing $\mathrm{x}$ fertilizer dose interactions. The resulting LSD $(5 \%)$ values were given in the tables.

\section{RESULTS AND DISCUSSION}

Statistically significant differences were observed in terms of row spacing, fertilizer dose and row spacing $\mathrm{x}$ fertilizer dose interactions for all features examined in the study and the LSD (5\%) values were indicated under the Tables.

\subsection{Vegetative shoot number}

Vegetative shoot found in 5 different $10-\mathrm{cm}$ unit areas in every plot were counted, this number was then multiplied with 10 to find the number in 1 meter and multiplied with area to obtain data for count $\mathrm{m}^{-2}$. The resulting data was listed in Table 3. 
Table 3. Values of Vegetative shoot number $\left(\right.$ count $\left.\mathrm{m}^{-2}\right)$ and Seed yield $\left(\mathrm{g} \mathrm{m}^{-2}\right)$.

\begin{tabular}{|c|c|c|c|c|c|c|c|c|c|c|c|}
\hline \multirow{3}{*}{ Years } & \multirow{3}{*}{$\begin{array}{l}\text { Row } \\
\text { Spac. } \\
(\mathrm{cm})\end{array}$} & \multicolumn{5}{|c|}{ Vegetative shoot number (count $\left.\mathbf{m}^{-2}\right)^{(*)}$} & \multicolumn{5}{|c|}{ Seed yield $\left(\mathrm{g} \mathrm{m}^{-2}\right)^{(* *)}$} \\
\hline & & \multicolumn{4}{|c|}{ Fertilizer Doses $\left(\mathrm{g} \mathrm{m}^{-2}\right)$} & \multirow{2}{*}{ Mean } & \multicolumn{4}{|c|}{ Fertilizer Doses $\left(\mathrm{g} \mathrm{m}^{-2}\right)$} & \multirow{2}{*}{ Mean } \\
\hline & & 0 & 10 & 20 & 30 & & 0 & 10 & 20 & 30 & \\
\hline \multirow{3}{*}{$1^{\text {st }}$} & 20 & 615 & 845 & 950 & 1034 & 861 & 70.7 & 107.4 & 144.9 & 161.8 & 121.2 \\
\hline & 40 & 504 & 655 & 790 & 921 & 718 & 54.6 & 105.9 & 129.4 & 156.5 & 111.6 \\
\hline & Mean & 560 & 750 & 870 & 978 & 789 & 62.9 & 107.1 & 137.5 & 159.6 & 116.8 \\
\hline \multirow{3}{*}{$2^{\text {nd }}$} & 20 & 683 & 886 & 1058 & 1166 & 948 & 81.3 & 120.1 & 165.2 & 185.8 & 138.1 \\
\hline & 40 & 542 & 711 & 824 & 961 & 760 & 58.8 & 122.2 & 154.1 & 177.3 & 128.1 \\
\hline & Mean & 613 & 799 & 941 & 1064 & 854 & 70.2 & 121.6 & 160 & 181.7 & 133.4 \\
\hline \multirow{3}{*}{$3^{\text {th }}$} & 20 & 641 & 861 & 1010 & 1097 & 902 & 78.2 & 113.7 & 153.6 & 175.5 & 130.3 \\
\hline & 40 & 521 & 679 & 811 & 939 & 738 & 54.7 & 112.8 & 144 & 167.5 & 119.8 \\
\hline & Mean & 581 & 770 & 911 & 1018 & 820 & 66.8 & 113.7 & 149.4 & 171.6 & 125.4 \\
\hline \multirow{3}{*}{ Mean } & 20 & 646 & 864 & 1006 & 1099 & 904 & 76.7 & 113.6 & 154.4 & 174.2 & 129.7 \\
\hline & 40 & 522 & 682 & 808 & 940 & 738 & 56 & 113.5 & 142.3 & 167 & 119.7 \\
\hline & Mean & 584 & 773 & 907 & 1020 & ---- & 66.6 & 114 & 148.9 & 170.9 & ---- \\
\hline \multicolumn{2}{|c|}{${ }^{(*)} \mathrm{LSD} 5 \%$} & $R S:$ & $\begin{array}{l}1^{\text {st }} 8.2 \\
2^{\text {nd }} 7.1\end{array}$ & $\begin{array}{l}3^{\text {th }} 7.3 \\
M .11 .4\end{array}$ & $F D:$ & $\begin{array}{l}1^{\text {st }} 14.5 \\
2^{\text {nd }} 13.8\end{array}$ & $\begin{array}{l}3^{\text {th }} 17.3 \\
M .16 .1\end{array}$ & $R S \times F D$ & $\begin{array}{l}1^{\text {st }} 13.9 \\
2^{\text {nd }} 13.1\end{array}$ & \multicolumn{2}{|c|}{$\begin{array}{l}3^{\text {th }} 13.5 \\
\text { M. } 15.4\end{array}$} \\
\hline \multicolumn{2}{|c|}{${ }^{(* *)} \operatorname{LSD} 5 \%$} & $R S:$ & $\begin{array}{l}1^{\text {st }} 2.31 \\
2^{\text {nd }} 2.22\end{array}$ & $\begin{array}{l}3^{\text {th }} 2.19 \\
\text { M. } 3.11\end{array}$ & $F D:$ & $\begin{array}{l}1^{s t} 4.41 \\
2^{\text {nd }} 4.26\end{array}$ & $\begin{array}{l}3^{\text {th }} 4.29 \\
\text { M. } 4.17\end{array}$ & $R S \times F D$ & $\begin{array}{l}1^{\text {st }} 1.42 \\
2^{\text {nd }} 1.34\end{array}$ & \multicolumn{2}{|c|}{$\begin{array}{l}3^{\text {th }} 1.29 \\
\text { M. } 1.28\end{array}$} \\
\hline
\end{tabular}

RS: Row Spacings, FD: Fertilizer Doses, $R S \times F D:$ Row Spacings $\times$ Fertilizer Doses, M.: Mean

When results were examined with regard to row spacing distance, higher values were obtained from the $20 \mathrm{~cm}$ row spacing than the $40 \mathrm{~cm}$ row spacing for all years of the research and for average values.

The highest value was measured in the $20 \mathrm{~cm}$ row spacing with 948 count $\mathrm{m}^{-2}$ in the second year. Assessment in terms of nitrogen doses revealed that highest values were identified in the $30 \mathrm{~g} \mathrm{~m}^{-2}$ dose, with a result of 1020 count $\mathrm{m}^{-2}$. Analysis of results for row spacing $\mathrm{x}$ fertilizer dose interactions showed highest vegetative shoot number values (1166 count $\mathrm{m}^{-2}$ ) in the $20 \mathrm{~cm}$ row spacing and $30 \mathrm{~g} \mathrm{~m}^{-2}$ fertilizer dose in the second year. In grasses, each germinated seed produces more than one shoot and this process is called "tillering". Some of the tillers grow panicles, but do not produce seeds. These are called a "Vegetative Shoot". On the other hand, those that do produce seeds are defined as "Generative Shoot" [10]. If the generative panicle number in a unit area is high, seed yield for grasses is affected positively $[1,2,6]$.

An increase in the generative shoot number is aimed by encouraging tillering with the use of nitrogen fertilizer when producing seed [25]. These results support the reports of many researchers $[14,16,17,20,23]$.

\subsection{Seed yield}

The average values for the amounts of seed taken from an area of $1 \mathrm{~m}^{2}$ in each plot are presented in Table 3 . Review of the data in terms of row spacing distance shows that higher values were obtained from the $20 \mathrm{~cm}$ row spacing in comparison to the $40 \mathrm{~cm}$ row spacing, for all years of the research and for average values. The highest value was determined in the $20 \mathrm{~cm}$ row spacing in the second year with a measurement of $138.1 \mathrm{~g} \mathrm{~m}^{-2}$. The study conducted by [22] achieved higher seed yield in the $20 \mathrm{~cm}$ row spacing and their values were similar to the results of our study.

Highest values with respect to nitrogen doses were observed in the $30 \mathrm{~g} \mathrm{~m}^{-2}$ dose, with a value of $170.9 \mathrm{~g} \mathrm{~m}^{-2}$ in average.

Analysis of results for row spacing $\times$ fertilizer dose interactions revealed highest seed values $\left(185.8 \mathrm{~g} \mathrm{~m}^{-2}\right)$ in the $20 \mathrm{~cm}$ row spacing and $30 \mathrm{~g} \mathrm{~m}^{-2}$ fertilizer dose in the second year. Application of higher doses of nitrogen created a positive effect on seed yield. Similar studies carried out in different ecological conditions [1,3,15,16,20,23] emphasized that the application of nitrogen fertilizer increased seed yield. Seed yields achieved in this study were higher than the values of numerous researchers $[9,11,13$ $21,23,26$,$] .$

\subsection{Straw yield}

The average values for the amounts of seed taken from an area of $1 \mathrm{~m}^{2}$ in each plot were presented in Table 4 . 
Table 4. Values of Straw yield $\left(\mathrm{g} \mathrm{m}^{-2}\right)$ and Biomass yield $\left(\mathrm{g} \mathrm{m}^{-2}\right)$.

\begin{tabular}{|c|c|c|c|c|c|c|c|c|c|c|c|}
\hline \multirow{3}{*}{ Years } & \multirow{3}{*}{$\begin{array}{l}\text { Row } \\
\text { Spac. } \\
(\mathrm{cm})\end{array}$} & \multicolumn{5}{|c|}{ Straw yield $\left(\mathrm{g} \mathrm{m}^{-2}\right)^{(*)}$} & \multicolumn{5}{|c|}{ Biomass yield $\left(\mathrm{g} \mathrm{m}^{-2}\right)^{(* *)}$} \\
\hline & & \multicolumn{4}{|c|}{ Fertilizer Doses $\left(\mathrm{g} \mathrm{m}^{-2}\right)$} & \multirow{2}{*}{ Mean } & \multicolumn{4}{|c|}{ Fertilizer Doses $\left(\mathrm{g} \mathrm{m}^{-2}\right)$} & \multirow{2}{*}{ Mean } \\
\hline & & 0 & 10 & 20 & 30 & & 0 & 10 & 20 & 30 & \\
\hline \multirow{3}{*}{$1^{\text {st }}$} & 20 & 636 & 1005 & 1214 & 1319 & 1044 & 707 & 1112 & 1359 & 1481 & 1165 \\
\hline & 40 & 597 & 889 & 1141 & 1287 & 979 & 652 & 995 & 1270 & 1444 & 1090 \\
\hline & Mean & 617 & 947 & 1178 & 1303 & 1011 & 680 & 1054 & 1315 & 1463 & 1128 \\
\hline \multirow{3}{*}{$2^{\text {nd }}$} & 20 & 676 & 1161 & 1261 & 1361 & 1115 & 757 & 1281 & 1426 & 1547 & 1253 \\
\hline & 40 & 641 & 1093 & 1188 & 1312 & 1059 & 700 & 1215 & 1342 & 1489 & 1187 \\
\hline & Mean & 659 & 1127 & 1225 & 1337 & 1087 & 729 & 1249 & 1384 & 1518 & 1220 \\
\hline \multirow{3}{*}{$3^{\text {th }}$} & 20 & 661 & 1048 & 1247 & 1341 & 1074 & 739 & 1162 & 1401 & 1517 & 1205 \\
\hline & 40 & 626 & 968 & 1155 & 1261 & 1003 & 681 & 1081 & 1299 & 1429 & 1123 \\
\hline & Mean & 644 & 1008 & 1201 & 1301 & 1038 & 710 & 1122 & 1350 & 1473 & 1164 \\
\hline \multirow{3}{*}{ Mean } & 20 & 658 & 1071 & 1241 & 1340 & 1078 & 734 & 1185 & 1395 & 1515 & 1207 \\
\hline & 40 & 621 & 983 & 1161 & 1287 & 1013 & 678 & 1097 & 1303 & 1454 & 1133 \\
\hline & Mean & 640 & 1027 & 1201 & 1314 & ---- & 706 & 1141 & 1349 & 1485 & ---- \\
\hline \multicolumn{2}{|c|}{${ }^{(*)} \mathrm{LSD} 5 \%$} & $R S:$ & $\begin{array}{l}1^{s t} 5.41 \\
2^{\text {nd }} 6.25\end{array}$ & $\begin{array}{l}3^{\text {th }} 6.11 \\
\text { M. } 5.17\end{array}$ & $F D:$ & $\begin{array}{l}1^{s t} 6.61 \\
2^{\text {nd }} 6.76\end{array}$ & $\begin{array}{l}3^{\text {th }} 5.42 \\
\text { M. } 5.23\end{array}$ & $R S \times F D$ & $\begin{array}{l}1^{s t} 4.32 \\
2^{n d} 4.11\end{array}$ & \multicolumn{2}{|c|}{$\begin{array}{l}3^{\text {th }} 5.22 \\
\text { M. } 4.23\end{array}$} \\
\hline \multicolumn{2}{|c|}{${ }^{(* *)} \operatorname{LSD} 5 \%$} & $R S:$ & $\begin{array}{l}1^{s t} 16.4 \\
2^{\text {nd }} 15.5\end{array}$ & $\begin{array}{l}3^{\text {th }} 18.1 \\
\text { M. } 17.7\end{array}$ & FD: & $\begin{array}{l}1^{s t} 19.1 \\
2^{\text {nd }} 66.6\end{array}$ & $\begin{array}{l}3^{\text {th }} 18.2 \\
\text { M. } 17.3\end{array}$ & $R S \times F D$ & $\begin{array}{l}1^{\text {st }} 15.2 \\
2^{\text {nd }} 14.2\end{array}$ & \multicolumn{2}{|c|}{$\begin{array}{l}3^{\text {th }} 15.6 \\
M .14 .2\end{array}$} \\
\hline
\end{tabular}

Review of the data in terms of row spacing distance shows that higher values were obtained from the $20 \mathrm{~cm}$ row spacing in comparison to the $40 \mathrm{~cm}$ row spacing, for all years of the research and for average values. The highest value was determined in the $20 \mathrm{~cm}$ row spacing in the second year with a measurement of $1115 \mathrm{~g} \mathrm{~m}^{-2}$. Highest values with respect to nitrogen doses were observed in the $30 \mathrm{~g} \mathrm{~m}^{-2}$ dose, with a value of $1314 \mathrm{~g} \mathrm{~m}^{-2}$ in average. Analysis of results for row spacing $\mathrm{x}$ fertilizer dose interactions revealed highest seed values $\left(1361 \mathrm{~g} \mathrm{~m}^{-2}\right)$ in the $20 \mathrm{~cm}$ row spacing and $30 \mathrm{~g} \mathrm{~m}^{-2}$ fertilizer dose in the second year. Straw yields achieved in this study were higher than the values of some researchers $[14,16,17,20,23]$.

\subsection{Biomass yield}

Yield values, obtained by adding the seed and shoot yield of each plot, are given in Table 4. As in seed yield and shoot yield values, review of the data in terms of row spacing distance shows that higher values were obtained from the 20 $\mathrm{cm}$ row spacing in comparison to the $40 \mathrm{~cm}$ row spacing, for all years of the research and for average values. The highest value was determined in the $20 \mathrm{~cm}$ row spacing in the second year with a measurement of $1253 \mathrm{~g} \mathrm{~m}^{-2}$. Highest values with respect to nitrogen doses were observed in the $30 \mathrm{~g} \mathrm{~m}^{-2}$ dose, with a value of $1485 \mathrm{~g} \mathrm{~m}^{-2}$ in average. Analysis of results for row spacing $\mathrm{x}$ fertilizer dose interactions revealed highest seed values $\left(1547 \mathrm{~g} \mathrm{~m}^{-2}\right)$ in the $20 \mathrm{~cm}$ row spacing and $30 \mathrm{~g}$ $\mathrm{m}^{-2}$ fertilizer dose in the second year. The results of the present study are higher than that of some researchers $[14,16,1720,23]$.

\subsection{Harvest index}

The harvest index values obtained by proportioning the biological yields to seed yields are given in Table 5 .

Table 5. Values of Harvest index (\%) and Winter endurance (1-9 point)

\begin{tabular}{|c|c|c|c|c|c|c|c|c|c|c|c|}
\hline \multirow{3}{*}{ Years } & \multirow{3}{*}{$\begin{array}{l}\text { Row } \\
\text { Spac. } \\
(\mathrm{cm})\end{array}$} & \multicolumn{5}{|c|}{ Harvest index $(\%)^{(*)}$} & \multicolumn{5}{|c|}{ Winter endurance (1-9 point) ${ }^{(* *)}$} \\
\hline & & \multicolumn{4}{|c|}{ Fertilizer Doses $\left(\mathrm{g} \mathrm{m}^{-2}\right)$} & \multirow{2}{*}{ Mean } & \multicolumn{4}{|c|}{ Fertilizer Doses $\left(\mathrm{g} \mathrm{m}^{-2}\right)$} & \multirow{2}{*}{ Mean } \\
\hline & & 0 & 10 & 20 & 30 & & 0 & 10 & 20 & 30 & \\
\hline \multirow{3}{*}{$1^{\text {st }}$} & 20 & 10.00 & 9.66 & 10.66 & 10.93 & 10.31 & 6.0 & 7.5 & 8.0 & 8.6 & 7.5 \\
\hline & 40 & 8.37 & 10.64 & 10.19 & 10.84 & 10.01 & 5.8 & 7.0 & 7.8 & 8.2 & 7.2 \\
\hline & Mean & 9.26 & 10.17 & 10.46 & 10.91 & 10.20 & 5.9 & 7.3 & 7.9 & 8.4 & 7.4 \\
\hline \multirow{3}{*}{$2^{\text {nd }}$} & 20 & 10.74 & 9.38 & 11.58 & 12.01 & 10.93 & 6.8 & 7.8 & 8.6 & 8.8 & 8.0 \\
\hline & 40 & 8.40 & 10.06 & 11.48 & 11.91 & 10.46 & 6.2 & 7.2 & 8.1 & 8.5 & 7.5 \\
\hline & Mean & 9.64 & 9.74 & 11.56 & 11.97 & 10.73 & 6.5 & 7.5 & 8.4 & 8.7 & 7.8 \\
\hline \multirow{3}{*}{$3^{\text {th }}$} & 20 & 10.58 & 9.78 & 10.96 & 11.57 & 10.72 & 7.2 & 7.9 & 8.4 & 8.8 & 8.1 \\
\hline & 40 & 8.03 & 10.43 & 11.09 & 11.72 & 10.32 & 7.1 & 7.5 & 8.1 & 8.6 & 7.8 \\
\hline & Mean & 9.41 & 10.14 & 11.07 & 11.65 & 10.57 & 7.2 & 7.7 & 8.3 & 8.7 & 8.0 \\
\hline \multirow{3}{*}{ Mean } & 20 & 10.44 & 9.59 & 11.07 & 11.50 & 10.65 & 6.7 & 7.8 & 8.6 & 8.8 & 8.0 \\
\hline & 40 & 8.26 & 10.35 & 10.92 & 11.49 & 10.25 & 6.4 & 7.2 & 8.0 & 8.4 & 7.5 \\
\hline & Mean & 9.43 & 9.99 & 11.04 & 11.51 & ---- & 6.5 & 7.5 & 8.3 & 8.6 & ---- \\
\hline \multicolumn{2}{|c|}{ (*) $^{*}$ LSD 5\% } & $R S:$ & $1^{s t} 0.01$ & $3^{\text {th }} 0.04$ & $F D:$ & $1^{s t} 0.05$ & $3^{\text {th }} 0.04$ & $R S \times F D$ & $1^{s t} 0.03$ & & \\
\hline
\end{tabular}




\begin{tabular}{|c|c|c|c|c|c|c|c|c|c|}
\hline & & $2^{\text {nd }} 0.03$ & M. 0.05 & & $2^{\text {nd }} 0.04$ & M. 0.06 & & $2^{\text {nd }} 0.04$ & M. 0.06 \\
\hline${ }^{(* *)} \operatorname{LSD} 5 \%$ & $R S:$ & $\begin{array}{l}1^{\text {st }} 0.02 \\
2^{\text {nd }} 0.01\end{array}$ & $\begin{array}{l}3^{\text {th }} 0.02 \\
\text { M. } 0.04\end{array}$ & $F D:$ & $\begin{array}{l}1^{\text {st }} 0.02 \\
2^{\text {nd }} 0.01\end{array}$ & $\begin{array}{l}3^{\text {th }} 0.03 \\
\text { M. } 0.03\end{array}$ & $R S \times F D$ & $\begin{array}{l}1^{\text {st }} 0.03 \\
2^{\text {nd }} 0.02\end{array}$ & $\begin{array}{l}3^{\text {th }} 0.02 \\
\text { M. } 0.04\end{array}$ \\
\hline
\end{tabular}

Review of the data in terms of row spacing distance shows that higher values were obtained from the $20 \mathrm{~cm}$ row spacing in comparison to the $40 \mathrm{~cm}$ row spacing, for all years of the research and for average values. The highest value was determined in the $20 \mathrm{~cm}$ row spacing in the second year with a measurement of $10.93 \%$. Highest values with respect to nitrogen doses were observed in the $30 \mathrm{~g} \mathrm{~m}^{-2}$ dose, with a value of $11.51 \%$ in average. Analysis of results for row spacing $\mathrm{x}$ fertilizer dose interactions revealed highest harvest yield values $(12.01 \%)$ in the $20 \mathrm{~cm}$ row spacing and $30 \mathrm{~g} \mathrm{~m}^{-}$ ${ }^{2}$ fertilizer dose in the second year. The lowest value $(8.03 \%)$ was determined in the third year in a $40 \mathrm{~cm}$ row spacing and $0 \mathrm{~g} \mathrm{~m}-2$ fertilizer dose.

The results of the present study are higher than that of some researchers $[14,16,17]$.

\subsection{Winter endurance}

The results obtained with scores (1: yellow, 9: dark green) given according to the yellowing conditions of grass in the months of December-January-February every year are given in Table 5. Review of the data in terms of row spacing distance shows that higher values were obtained from the 20 $\mathrm{cm}$ row spacing in comparison to the $40 \mathrm{~cm}$ row spacing, for all years of the research and for average values.

The highest value was determined in the $20 \mathrm{~cm}$ row spacing in the third year with a measurement of 8.1 points. Highest values with respect to nitrogen doses were observed in the $30 \mathrm{~g} \mathrm{~m}^{-2}$ dose, with a value of 8.6 point in average. Analysis of results for row spacing $\mathrm{x}$ fertilizer dose interactions revealed highest harvest yield values ( 8.8 points) in the 20 $\mathrm{cm}$ row spacing and $30 \mathrm{~g} \mathrm{~m}^{-2}$ fertilizer dose in the second and third years. The lowest value (5.8 points) was determined in the first year in a $40 \mathrm{~cm}$ row spacing and $0 \mathrm{~g} \mathrm{~m}^{-2}$ fertilizer dose.

Findings obtained in the research are similar to those of some researchers $[14,16,17]$.

\section{CONCLUSION AND SUGGESTIONS}

The following results were reached with a holistic analysis of the values obtained in this study with consideration to the effect of different row spacings $(20$ and $40 \mathrm{~cm})$ and different nitrogen fertilizer doses $\left(0,10,2030 \mathrm{~g} \mathrm{~m}^{-2}\right)$ on the seed yield and certain botanical characteristics of the "Rebel XLR" variety of Festuca arundinacea.

When the data is examined in terms of row spacings; $20 \mathrm{~cm}$ row spacings gave higher values. In general, annual rainfall is sufficient, and when rainfall is sufficient and evenly spread throughout the season, seed yield increases due to the fact that there is more plant per unit area $[1,3,6]$.
When the data is examined in terms of nitrogen dosing applications, the highest values were obtained in the $30 \mathrm{~g} \mathrm{~m}^{-}$ 2 fertilizer dose. Many researchers [1,2,3,4,8,9,11,13$21,23,26$,] indicate that increasing doses of nitrogen fertilizer application increases seed yield, and the results of this study validate this thesis.

Row spacing distance and fertilizer doses, components applied to data obtained in this study, were not the only factors affecting the performance of sown plants; the climate also played an important role. Long term average climatic data for the research area showed total annual precipitation at a value of $685.9 \mathrm{~mm}$ and annual average temperature at $14.7^{\circ} \mathrm{C}$ (Table 1). Furthermore, the research area had 128.6 days of rain and cool temperatures (average $14.7^{\circ} \mathrm{C}$ ) in a year, according to long term data. It is possible to say that climatic date pertaining to the years of the research revealed close to ideal conditions especially in terms of the precipitation and temperature required to cultivate coolseason turf plants, among which Festuca arundinacea can be counted, with the purpose of producing seed and also a suitable ecology for the plants to enhance in full performance $[1,3]$ Climatic differences between the years is a totally natural and unpreventable reality, which was also reflected onto the data of the research. Highest data was detected in the $2^{\text {nd }}$ year, when rainfall was heaviest; and lowest values were observed in the $3^{\text {rd }}$ year, when there was least rainfall and highest temperatures.

With an overall evaluation of the characteristics examined in the study, and in consideration of the seed yield and some important characteristics of the Festuca arundinacea plant; it can be said that this plant is suitably cultivated in the 20 $\mathrm{cm}$ row spacing and $30 \mathrm{~g} \mathrm{~m}^{-2}$ nitrogen dose; which provided a seed yield of $161.8 \mathrm{~g} \mathrm{~m}^{-2}$ in the $1^{\text {st }}$ year, $185.8 \mathrm{~g} \mathrm{~m}^{-2}$ in the $2^{\text {nd }}$ year, $175.5 \mathrm{~g} \mathrm{~m}^{-2}$ in the $3^{\text {rd }}$ year and $174.2 \mathrm{~g} \mathrm{~m}^{-2}$ in average according to our study results. However, there is no knowledge concerning the effects of higher doses than those administered in this research on the examined properties, particularly on seed yield. For this reason, it is clear that more research needs to be conducted with different row spacings, different doses and different fertilizer types in order to obtain reliably healthy and explanatory results.

\section{REFERENCES}

[1] N. Açkgöz, E. İlker ve A. Gökçol, "Bilgisayarda Biyolojik Araştırmaların Değerlendirilmesi”, Ege Üniv., TOTEMSTAT, (2004).

[2] E. Açıkgöz,."Çim Alanlar Yapım ve Bakım Tekniği”,, Uludağ Üniversitesi Ziraat Fakültesi, Bursa, 203, (1994).

[3] E. Açıkgöz, "Yem Bitkileri”. Yenilenmiş Baskı. Uludağ Üniversitesi Güçlendirme Vakfı Yayın No: 82, (2001).

[4] Anonymous, http://www.tarim.gov.tr/ BUGEM /TTSM/Belgeler/Tescil/Teknik\%20.Talimatlar/Ye 
m\%20Bitkileri/Bu\%C4\%9Fdaygil\%20Yem\%20Bitkileri/01 cim.pdf, (2014).

[5] Anonymous, http://www.tarim.gov.tr/Konular /BitkiselUretim/Tohumculuk/Tohumculuk-Istatistikleri, (2017).

[6] R. Avcıŏlu ve H. Soya, "Akdeniz İklimine Uygun Bazı Yeşil Alan Buğdaygillerinde Vejetatif Tohumluk Üretimi ile Vejetasyon Özellikleri Üzerinde Araştırmalar." TUBİTAK Proje No: TOAG-879, Bornova-İzmir, (1996).

[7] R. Avcıŏlu, "Çim Ekimi Dikimi Bakımı”. Ege Üniversitesi Yayınları, Ziraat Fakültesi Yayın No: 574, Bornova-İzmir, $332 \mathrm{~s}$, (2014).

[8] J.B. Beard, “Turfgrass Science and Culture”. Englewood Cliffs, N, J. Printice Hall, London, (1973).

[9] U. Bilgili and E. Aç1kgöz, "Year-Round Nitrogen Fertilization Effects on Growth and Quality of Sports Turf Mixtures”, Journal of Plant Nutrition, 28 (2): 299-307, (2005).

[10] A.R. Brohi ve A. Aydeniz, "Gübreler ve Gübreleme”, Cumhuriyet Üniv., Ziraat Fakültesi Yayınları: 10, Ders Kitabı: 3, Tokat, 880 s, (1991).

[11] C.L. Canode, "Influence of Row Spacing and Nitrogen Fertilization on Grass Seed Production". Agronomy Journal, 60 (3): 263-267, (1967).

[12] S.T. Cockerham, V.A. Gibeault, J.V. Dam and M.K. Leonard,. "Tolerance of Cool Season Turfgrasses to Sports Traffic, Turfgrass-Culture”. University of California, Riverside, CA 92521, USA, (1989).

[13] M.S. Gençkan, “Yembitkileri Tarımı”. Ege Üniversitesi, Ziraat Fakültesi Yayınları No: 417, Bornova - İzmir, 519 s., (1983).

[14] N. Grossi, M. Volterrani, S.Magni and S. Miele, "Tall Fescue Turf Quality and Soccer Playing Characteristics as Affected by Mowing Height”. Acta Hort. (Ishs) 661:319-322, (2004).

[15] F. Hope,. "Rasen”, Verlag Eugen Ulmer, Stuttgart, Germany, 216 pp, (1983).

[16] B. Huang and H. Gao, "Root Physiological Characteristics Associated with Drought Resistance in Tall Fescue Cultivars", Crop Science, 40: 196-203, (2000).

[17] A.F. Kelly, "Seed Production of Agricultural Crops", Longman Scientific \& Technical Copublished in the U. S. With John Wiley \& Sons, Inc., 227 p, (1988).

[18] E. Kün, "Serin İklim Tahıllar”,. Ankara Üniversitesi, Ziraat Fakültesi Yayınları: 875, Ders Kitabı: 240, Ankara, $307 \mathrm{~s},(1983)$.

[19] S. Miele, M. Volterrani, S, Magni and M. Gaetani, "Winter Quality of Tall Fescue Turfs, Effect of Renovation Technique and Nitrogen Fertilization", Dipartimento di
Agronomia e Gestione dell' Agroecosistema, Universita di Pisa, Italy. Italy Jou. of Argonomy, 6, 2, 97-101, (2002). [20] İ. Nizam, "İki Buğdaygil Bitkisinde Farkl Dozlarda Azot Uygulamalarinin Ot ve Tohum Verimleri ile Verime Etkili Karakterler Üzerinde Etkileri. (PhD. Thesis). Trakya Üniversitesi, Fen Bilimleri Enstitüsü, Tekirdağ, 136, 2004). [21] A. Patton, and J. Boyd, "Choosing a Grass for Arkansas Lawns", Agriculture and Natural Resources, Cooperative Extension Service, FSA2112, (2007).

[22] L. Russi, P. Annicchiarico, P. Martiniello, C. Tomasoni, E. Piano and F. Veronesi,. "Turf Quality of Cool Season Grasses at Low Inputs: Reliability Across Years, Seasons and Sites of Evaluation", Acta Horticulturae, No. 661: $387-$ 392, (2004).

[23] A. Salman, B. Budak, B. Kır, E.V. Küçükerbaş, ve M. Yılmaz, "Farklı gübre dozlarının çok yıllık çim (Lolium perenne L.) ve kamışsı yumak (Festuca arundinacea Shreb.) çim türlerinde tohum verimi ve bazı bitkisel özellikleri üzerine etkisi”, Ege Ün., Proje Raporu, Proje No: 14BAMYO_001, İzmir, 62, (2017).

[24] A. Simic, S. Vuckovic, R. Maletic, D. Sokolovic. and $\mathrm{N}$. Djordjevic, "The impact of seeding rate and inter-row spacing on Italian ryegrass for seed in the first harvest year', Turkish Journal of Agriculture and Forestry, 33, 425433, (2009).

[25] K.S. Walker, C.A. Bigelow, D.R. Smith, G.E. Van Scoyoc and Z.J. Reicher, "Aboveground Responses of CoolSeason Lawn Species to Nitrogen Rates and Application Timings", Crop. Science, 47:1225-1236, (2007).

[26] M. Y1lmaz, "Yeşil Alan ve Erozyon Kontrol Bitkisi Olarak Kullanılan Bazı Buğdaygillerin Tokat Şartlarında Yeşil Alana Uygunluklarl ve Tohum Verimleri Üzerinde Araştırmalar”, (Doktora Tezi) Ege Ü., İzmir, 220, (2000).

[27] M. Yılmaz ve R. Avcıoğlu, "Erozyon Kontrolünde Kullanılan Bazı Buğdaygillerin Tokat Koşullarında Tohum Verimlerinin Belirlemesi",. Türkiye 4. Tarla Bitkileri kongresi, 17-21 Eylül 2001, Tekirdağ, s. 149-154, (2001).

[28] M. Yılmaz ve R. Avcıŏlu, "Yeşil Alan Tesisinde Kullanılan Bazı Buğdaygillerin Tokat Koşullarında Bazı Agronomik Özellikleri ve Tohum Verimlerinin Belirlemesi", Gaziosmanpaşa Üni.. Ziraat Fakültesi Dergisi, 19 (1): $87-$ 95, (2002).

[29] W.C. Young III, G.A. Mellbye, G.A. Gingrich, T.B. Silberstein, S.M. Griffith, T.G. Chastain and J.M. Hart, "Defining optimum nitrogen fertilization practices for grass seed production systems in the Willamette Valley. http://cropandsoil.oregonstate. edu/seed-ext/Pub/ 2000/01. pdf. (2001). 